\title{
PENENTUAN KOMODITAS UNGGULAN SUB SEKTOR TANAMAN PANGAN DAN HORTIKULTURA DI SETIAP KECAMATAN KABUPATEN TASIKMALAYA
}

\section{DETERMINING THE LEADING COMMODITIES OF THE FOOD CROPS AND HORTICULTURE SUB SECTOR IN EACH DISTRICT OF TASIKMALAYA REGENCY}

\author{
Yayu Setiani, Unang*, Betty Rofatin \\ Jurusan Agribisnis, Fakultas Pertanian, Universitas Siliwangi \\ *E-mail corresponding : unang@unsil.ac.id
}

\begin{abstract}
ABSTRAK
Tujuan penelitian untuk mengidentifikasi komoditas tanaman pangan dan hortikultura basis, komoditas prioritas pengembangan dan komoditas yang dapat diunggulkan di 39 wilayah masing-masing Kecamatan Kabupaten Tasikmalaya,. Metode penelitian yang digunakan adalah studi kasus dengan menganalisis nilai LQ dan analisis Shift Share. Hasil penelitian berdasarkan 5 komoditas dengan sebaran terbanyak di setiap kecamatan, menunjukkan bahwa komoditas tanaman pangan dan hortikultura yang menjadi basis di wilayah Kecamatan di Kabupaten Tasikmalaya adalah padi (tersebar di 22 kecamatan), pisang (tersebar di 15 kecamatan), belimbing, durian, dan kangkung (tersebar di 14 kecamatan). Komoditas tanaman pangan dan hortikultura yang menjadi prioritas pengembangan utama yaitu padi (tersebar di 22 kecamatan), belimbing, durian, kangkung dan kacang panjang (tersebar di 14 kecamatan yang berbeda). Kemudian untuk komoditas tanaman pangan dan hortikultura yang menjadi unggulan yaitu padi (tersebar di 13 kecamatan), jagung, kedelai dan jambu biji (tersebar di 8 kecamatan), dan nangka (tersebar di 7 kecamatan).
\end{abstract}

Kata kunci: Prioritas pengembangan, komoditas unggulan, tanaman pangan dan hortikultura, LQ, Shift Share.

\begin{abstract}
The purpose of the study was to identify basis of food crops and horticulture commodities, development priority commodities and commodities that can be seeded in 39 regions of each District of Tasikmalaya Regency. The Research Method is a case study by applying $L Q$ and Shift Share Analysis. The results of the study were based on 5 commodities with the most distribution in each sub-district, showed that the commodities of food crops and horticultures which became the basis in the districts in Tasikmalaya Regency were rice (spread in 22 sub-districts), bananas (spread in 15 sub-districts), starfruit, durian, and water spinach (spread in 14 sub-districts). The commodity of food crops and horticulture which is the priority of the main development, namely rice (spread in 22 sub-districts), starfruit, durian, water spinach and long beans (spread in 14 sub-districts). Furthermore for the commodity of food crops and horticulture which become superior, namely rice (spread in 13
\end{abstract}




\section{PENENTUAN KOMODITAS UNGGULAN SUB SEKTOR TANAMAN PANGAN DAN HORTIKULTURA DI SETIAP KECAMATAN KABUPATEN TASIKMALAYA \\ Yayu Setiani, Unang dan Betty Rofatin}

sub-districts), corn, soybeans and guava (spread in 8 sub-districts), and jackfruit (spread in 7 sub-districts).

Keywords: Development priorities, leading Commodities, food crops and horticulture, $L Q$, shift share.

\section{PENDAHULUAN}

Dalam rangka tercapainya pembangun-an daerah maka pemerintah daerah harus mengetahui potensi yang dimiliki oleh daerah atau wilayahnya dengan memper-hatikan perekonomian masyarakat, potensi sumberdaya alam, sumberdaya manusia dan infrastruktur. Pembangunan ekonomi dapat diukur berdasarkan besaran nilai dari produk domestik regional bruto (PDRB)nya.
Menurut Suyatno (2000), pembangunan daerah dapat diarahkan untuk memberdaya-kan potensi alam agar dapat lebih berdaya guna dan berhasil guna dalam meningkatkan hasil daerah. Selain itu, masing-masing wilayah perlu untuk menen-tukan komoditas unggulan agar pemba-ngunan daerah dimasa yang akan datang dapat diarahkan pada pengembangan ko-moditas unggulan tersebut.

Tabel 1. Angka Produk Domestik Regional Bruto (PDRB) Kab. Tasikmalaya Tahun 2017-2019 (Rp 000)

\begin{tabular}{clccc}
\hline & Lapangan Usaha & $\mathbf{2 0 1 7}$ & $\mathbf{2 0 1 8}$ & $\mathbf{2 0 1 9}$ \\
\hline $\mathbf{A}$ & Pertanian, Kehutanan, dan Perikanan & 7.780 & 8.031 & 8.157 \\
$\mathbf{C}$ & Industri Pengolahan & 1.655 & 1.818 & 1.969 \\
$\mathbf{F}$ & Konstruksi & 1.917 & 2.064 & 2.238 \\
$\mathbf{G}$ & Perdagangan Besar dan Eceran & 4.482 & 4.698 & 5.040 \\
$\mathbf{J}$ & Informasi dan Komunikasi & 1.035 & 1.138 & 1.263 \\
$\mathbf{O}$ & Administrasi pemerintahan, & 962 & 960 & 1.014 \\
& Pertahanan dan Jaminan Sosial Wajib & & & \\
$\mathbf{P}$ & Jasa Pendidikan & 1.457 & 1.604 & 1.692 \\
\hline & Produk Domestik Bruto & 22.063 & 23.319 & 24.587 \\
\hline
\end{tabular}

Sumber : BPS Kabupaten Tasikmalaya (2020)

Berdasarkan Tabel 1, kontribusi

Sektor Pertanian terhadap PDRB Kabupaten Tasikmalaya tahun 20172019 memiliki sumbangan terbesar dibandingkan dengan sektor lainnya. Kontribusi yang besar harus diikuti dengan peningkatan kesejahteraan masyarakat melalui penyerapan tenaga kerja yang dapat dilakukan dengan mengetahui sub sektor mana yang menjadi sektor unggulan, sehingga dapat diketahui komoditas unggulan, yang mana sektor tersebut diharapkan akan dapat menyerap tenaga kerja dan meningkatkan perekonomian masyarakat.

Salah satu sasaran pembangunan ekonomi wilayah jangka panjang adalah 
ter-jadinya pergeseran pada struktur ekonomi wilayah yang terjadi karena diakibatkan kemajuan pembangunan suatu wilayah. Tidak semua sektor atau subsektor dalam perekonomian memiliki kemampuan tumbuh yang sama. Oleh sebab itu, perencana pembangunan wilayah biasanya akan memanfaatkan sektor-sektor atau subsetor-subsektor basis yang dianggap dapat mendorong pertumbuhan ekonomi wilayah (Arief dan Yundy, 2010).

Kemudian hasil produksi sub sektor tanaman pangan dan hortikultura menurut Dinas Pertanian, Pangan dan Perikanan Kabupaten Tasikmalaya tahun 2019 meru-pakan sub sektor penyumbang terbesar. Oleh sebab itu sub sektor ini dapat diharapkan dalam usaha meningkatkan pendapatan daerah khususnya di tingkat kecamatan agar setiap wilayah kecamatan dapat maju dan berkembang. Disamping itu, sub sektor tanaman pangan dan hortikultura merupakan komoditas yang mencakup kebutuhan pokok manusia sehingga sangat diperlukan penelitian yang mendalam agar sub sektor tanaman pangan dan hortikultura dapat berkembang menjadi lebih baik dan dapat memenuhi kebutuhan hidup masyara-kat secara kontinu.

Komoditas pertanian sub sektor tanaman pangan dan hortikultura yang dihasilkan di Kabupaten Tasikmalaya tersebar di 39 kecamatan. Berbagai macam komoditas tanaman pangan dan hortikultura yang dihasilkan di Kabupaten Tasikmalaya,perlu diketahui peran setiap komoditas pada subsektor tersebut.

Untuk menentukan dan mengenali potensi sub sektor tanaman pangan dan hortikultura yang dihasilkan di masingmasing kecamatan, maka perlu diidentifikasi komoditas mana yang merupakan komodi-tas basis, sehingga dapat diunggulkan dan menjadi prioritas untuk dikembangkan dengan lebih terarah dan efisien pada masa mendatang guna menghadapi persaingan di era otonomi daerah.

\section{METODE PENELITIAN}

Metode penelitian yang digunakan adalah studi kasus terhadap sub sektor tanaman pangan dan hortikultura di Kabupaten Tasikmalaya. Jenis data yang digunakan dalam penelitian ini adalah data sekunder produksi komoditas tanaman pangan dan hortikultura (tanaman pangan, sayuran dan buahbuahan) masing-masing kecamatan di Kabupaten Tasikmalaya.yaitu berupa data time series selama 5 tahun (20162020). Data diperoleh dari instansi pemerintah atau lembaga terkait diantaranya Dinas Pertanian, Pangan dan Perikanan Kabupaten Tasikmalaya, Badan Pusat Statistik (BPS) Kabupaten Tasikmalaya. 


\section{PENENTUAN KOMODITAS UNGGULAN SUB SEKTOR TANAMAN PANGAN DAN HORTIKULTURA DI SETIAP KECAMATAN KABUPATEN TASIKMALAYA \\ Yayu Setiani, Unang dan Betty Rofatin}

\section{A. Analisis Location Quotient}

Analisis Location Quotient (LQ) digunakan untuk menentukan basis dan non basis sub sektor tanaman pangan dan hortikultura serta komoditas unggulan wilayah maupun komoditas unggulan dari daerah. Analisis Location Quotient dapat dirumuskan sebagai berikut :

$$
\mathrm{LQ}=\frac{S i / S}{N i / N}
$$

Keterangan:

LQ : Indeks Location Quotient komoditas sub sektor tanaman pangan dan hortikultura $i$ pada tingkat Kecamatan di Kabupaten Tasikmalaya.

$\mathrm{S}_{\mathrm{i}}$ : Produksi komoditas sub sektor tanaman pangan dan hortikultura $i$ di Kecamatan Kabupaten Tasikmalaya.

S : Produksi total komoditas sub sektor tanaman pangan dan hortikultura di Kecamatan Kabupaten Tasikmalaya.

$\mathrm{N}_{\mathrm{i}}$ : Produksi komoditas sub sektor tanaman pangan dan hortikultura $i$ di Kabupaten Tasikmalaya.

$\mathrm{N}$ : Produksi total komoditas sub sektor tanaman pangan dan hortikultura di Kabupaten Tasikmalaya. Indikator :

a. $L Q>1$, artinya komoditas petanian tersebut termasuk komoditi basis.

b. $L Q<1$, artinya komoditas petanian tersebut termasuk komoditi non basis.

c. $L Q=1$, artinya komoditas petanian tersebut telah mencukupi dalam kegiatan tertentu (seimbang).

\section{B. Metode Analisis Shift Share}

Analisis Shift Share terdiri dari tiga komponen yaitu Komponen Pertumbuhan Nasional (PN)/(daerah acuan), Komponen Pertumbuhan Proporsional (PP), dan Komponen Pertumbuhan Pangsa Wilayah (PPW) (Field dan Mac Gregor,1993)

Analisis Shift Share dapat dinyatakan sebagai berikut (Arief dan Yundy, 2010):

$$
\Delta Y i j=P N i j+P P i j+P P W i j
$$

Komponen Pertumbuhan Nasional

$P N_{i j}=\left(R_{a}-1\right) Y_{i j}$

Komponen Pertumbuhan Proporsional

$P P_{i j}=\left(R_{i}-R_{a}\right) Y_{i j} A$ tauY' ${ }^{\prime}{ }_{i j}-Y_{i j}=Y_{i j}\left(R_{a}-1\right)+$ $Y_{i j}\left(R_{i}-R_{a}\right)+Y_{i j}\left(r_{i}-R_{a}\right)$

Dimana :

$$
\begin{aligned}
& r_{i}=Y^{\prime}{ }_{i j}-Y_{i j} / Y_{i j} \\
& R_{i}=Y^{\prime}{ }_{i j} / Y_{i j} \\
& R_{a}=Y^{\prime} \ldots / Y \ldots
\end{aligned}
$$

Komponen Pertumbuhan Pangsa

Wilayah

$$
\begin{aligned}
P P W_{i j}=Y_{i j}\left(r_{i}-R_{i}\right), \text { dimana }: r_{i} & =Y^{\prime}{ }_{i j}-Y_{i j} / Y_{i j} ; \\
R_{i} & =Y^{\prime}{ }_{i} / Y_{i}
\end{aligned}
$$

Keterangan

$Y_{i j}$ : Produksi komoditas sub sektor tanaman pangan dan hortikultura $i$ pada wilayah kecamatan $j$ di Kabupaten Tasikmalaya pada tahun dasar analisis.

$Y^{\prime}$ ij : Produksi komoditas sub sektor tanaman pangan dan hortikultura $i$ pada wilayah kecamatan $j$ di Kabupaten Tasikmalaya pada tahun akhir analisis.

PPW $W_{i j}$ : Pertumbuhan pangsa wilayah komoditas sub sektor tanaman pangan dan hortikultura $i$ pada wilayah kecamatan $j$ di Kabupaten Tasikmalaya.

$\mathrm{PN}_{\mathrm{ij}}$ : Pertumbuhan nasional sub sektor tanaman pangan dan hortikultura $i$ di Kabupaten Tasikmalaya.

$\mathrm{PP}_{\mathrm{ij}}$ : Pertumbuhan proporsional komoditas sub sektor tanaman pangan dan hortikultura $i$ di Kabupaten Tasikmalaya.

$\left(R_{i}-R_{a}\right)$ : Presentase perubahan komoditas tanaman pangan dan hortikultura yang disebabkan oleh komponen pertumbuhan proporsional (\%).

$\left(r_{i}-R_{i}\right)$ : Presentase perubahan produksi komoditas sub sektor tanaman pangan dan hortikultura yang disebabkan komponen pertumbuhan pangsa wilayah (\%). 
$Y_{i}=\sum Y_{i j}$ : Produksi komoditas sub sektor tanaman pangan dan hortikultura $i$ pada wilayah Kabupaten Tasikmalaya pada tahun dasar analisis.

$Y^{\prime}{ }_{i}=\sum Y^{\prime}{ }_{i j}:$ Produksi komoditas sub sektor tanaman pangan dan hortikultura $i$ pada wilayah Kabupaten Tasikmalaya pada tahun akhir analisis.

Y... : Produksi seluruh sub sektor tanaman pangan dan hortikultura Kabupaten Tasikmalaya pada tahun dasar analisis.

$Y^{\prime}$... : Produksi seluruh sub sektor tanaman pangan dan hortikultura Kabupaten Tasikmalaya pada tahun akhir analisis.

Indikator :

a. Apabila PP bernilai positif berarti bahwa komoditas sub sektor tanaman pangan dan hortikultura (i) kecamatan yang dianalisis (j) tumbuh dengan cepat. Apabila PP bernilai negatif maka berrati bahwa komoditas susb sektor tanaman pangan dan hortikultura (i) kecamatan yang dianalisis (j) tumbuh dengan lambat.

b. Apabila PPW bernilai positif berarti bahwa komoditas sub sektor tanaman pangan dan hortikultura (i) kecamatan yang dianalisis (j) mempunyai keuntungan kompetitif atau berdaya saing jika dibandingkan dengan komoditas sub sektor tanaman pangan dan hortikultura yang sama di Kabupaten Tasikmalaya. Apabila PPW bernilai negatif maka berarti bahwa komoditas sub sektor tanaman pangan dan hortikultura (i) kecamatan dianalisis (j) tidak mempunyai keuntungan kompetitif atau tidak berdaya saing jika dibandingkan dengan komoditas sub sektor tanaman pangan dan hortikultura yang sama di Kabupaten Tasikmalaya.

\section{HASIL DAN PEMBAHASAN}

\section{A. Identifikasi Komoditas Basis di Setiap Kecamatan}

Menghitung nilai LQ dari setiap komoditas sub sektor tanaman pangan dan hortikultura yang dihasilkan Kabupaten Tasikmalaya dapat menunjukkan kekuatan atau besar kecilnya peranan suatu komoditas dalam suatu kecamatan dibandingkan dengan Kabupaten Tasikmalata. Komoditas yang menjadi basis tersebut akan mendukung jalannya perekonomian daerah, dan komoditas tersebut dapat diekspor ke luar daerah. Adanya arus pendapatan dari luar daerah ini akan menyebabkan kenaikan konsumsi dan investasi yang berdampak pada kenaikan pendapatan dan diharapkan menciptakan kesempatan kerja baru kecamatan tersebut.

Komoditas sub sektor tanaman pangan dan hortikultura di wilayah masing-masing kecamatan di Kabupaten Tasikmalaya tahun 2016-2020 berdasarkan hasil analisis LQ rata-rata dapat dilihat pada Tabel 2. Tabel tersebut menunjukkan bahwa komoditas sub sektor tanaman pangan dan hortikul-tura basis masing-masing kecamatan di Kabupaten Tasikmalaya adalah padi, jagung, kedelai, kacang tanah, kacang hijau, ubi kayu, ubi jalar, belimbing, jambu biji, jambu air, mangga, nenas, pisang, sirsak, sawo, rambutan, durian, petai, duku, jeruk besar, jeruk keprok, nangka, pepaya, melinjo, sukun, salak pondoh, salak lokal, manggis, alpukat, bawang daun, kubis, cabe rawit, tomat, buncis, mentimun, cabe besar, petsai, terung, kangkung, bayam, kacang merah, dan kacang panjang. 


\section{PENENTUAN KOMODITAS UNGGULAN SUB SEKTOR TANAMAN PANGAN DAN HORTIKULTURA DI SETIAP KECAMATAN KABUPATEN TASIKMALAYA}

Yayu Setiani, Unang dan Betty Rofatin

Mencermati Tabel 2 tersebut, Kecamatan Cibalong memiliki jumlah komoditas basis terbanyak diantara yang lain yaitu sebanyak 24 komoditas. Hal tersebut didukung oleh kondisi lingkungan Kecamatan Cibalong yang cocok untuk pengembangan komoditas tanaman pangan dan hortikultura yaitu Kecamatan Cibalong berada pada ketinggian 0-500 mdpl dan beriklim tropis, hal ini sesuai dengan yang dilaporkan Budiman dan Ris (2014) bahwa semakin rendah topografi tempat tumbuh, semakin beragam pola tanam dan jenis tanaman yang dapat dikembangkan. Total luas wilayah Kecamatan Cibalong sebagian besar dimanfaatkan sebagai bangunan/pekarangan, sedangkan lahan sawah seluas $1.932 \mathrm{Ha}$, dan lahan tanaman hortikultura seluas $644 \mathrm{Ha}$.

Tabel 2. Komoditas Sub Sektor Tanaman Pangan dan Hortikultura Basis di Setiap Kecamatan Tahun 2016-2020

\begin{tabular}{|c|c|c|c|c|c|c|c|c|c|c|c|c|c|c|c|}
\hline \multirow[t]{2}{*}{ No } & \multirow[t]{2}{*}{ Kecamatan } & \multicolumn{14}{|c|}{ Komoditas } \\
\hline & & 1 & 2 & 3 & 4 & 5 & 6 & 7 & 8 & 9 & 10 & 11 & 12 & 13 & 14 \\
\hline$;$ & C.motush & & & & & $\mathrm{R}$ & $\frac{R}{R}$ & $N R$ & & R & NR & $\mathrm{NR}$ & $\mathrm{R}$ & R & $\sqrt{R}$ \\
\hline$\frac{2}{3}$ & $\begin{array}{l}\text { Karanomenesal } \\
\text { Cikaloen }\end{array}$ & N & 13 & 8 & $\stackrel{A}{B}$ & $\mathrm{NB}$ & $\frac{R}{B}$ & AB & NB & $\frac{k}{3}$ & NB & $\mathrm{NB}$ & $\frac{\pi}{N B}$ & B & $\mathrm{NT}$ \\
\hline 7 & Panexenning & $\mathrm{NB}$ & B & & $\mathrm{NB}$ & $\mathrm{NB}$ & $\mathrm{NB}$ & $\bar{B}$ & & $\mathrm{~A} \overline{\mathrm{B}}$ & $\mathrm{NB}$ & B & $\mathrm{NB}$ & B & $\frac{D}{N B}$ \\
\hline 4 & Cibatrmat & 视 & $\overrightarrow{\mathrm{B}}$ & & $\mathrm{B}$ & 露 & $\mathrm{B}$ & $\sqrt{B}$ & & $\mathrm{~N}$ & $\sqrt{B}$ & $\mathrm{~B}$ & N & $\vec{B}$ & 栉 \\
\hline 6 & Cibuloseg & NB & B & B & B & $\mathrm{NB}$ & B & B & NB & B & B & B & $\mathrm{NB}$ & B & B \\
\hline 7 & $\begin{array}{l}\text { Paruazocateng } \\
\text { Rumbrhalmes }\end{array}$ & $\mathrm{NB}$ & & & B & $\mathrm{NB}$ & $\frac{\mathrm{B}}{\mathrm{H}}$ & $\frac{B}{N B}$ & $\frac{\mathrm{B}}{\mathrm{B}}$ & $\frac{B}{B}$ & $\frac{\mathrm{NB}}{\mathrm{B}}$ & $\mathrm{NB}$ & $\mathrm{NB}$ & B & $\frac{N B}{B}$ \\
\hline in & Bowonganih & $\mathrm{NB}$ & $\sqrt{3}$ & & $\mathrm{NB}$ & $\mathrm{NB}$ & $\frac{1}{B}$ & $\mathrm{~B}$ & & $\frac{D}{B}$ & $B$ & $B$ & $\mathrm{~B}$ & & $\frac{n}{B}$ \\
\hline in & $\begin{array}{l}\text { Chumera } \\
\text { Romnneramher }\end{array}$ & R & $\mathrm{N}$ & NR & $\mathrm{NB}$ & $\mathrm{NB}$ & $N_{R}^{B}$ & $N_{R}^{B}$ & & $\mathrm{NB}$ & $\mathrm{N}_{\mathrm{R}}$ & $\mathrm{NB}$ & $\mathrm{NB}$ & $\frac{B}{B}$ & $\frac{N B}{R}$ \\
\hline 12 & Sodonikilir & 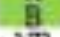 & $\mathrm{NB}$ & $\mathrm{NB}$ & $\mathrm{NB}$ & $B$ & $\mathrm{~B}$ & $\mathrm{~A}$ & & $\mathrm{NB}$ & B & B & $\mathrm{NB}$ & & \\
\hline 15 & Tram & $\mathrm{NR}$ & $\mathrm{NR}$ & & NR & $\mathrm{NR}$ & $\frac{N R}{B}$ & $\mathrm{R}$ & & $\sqrt{3}$ & NR & R & $\sqrt{B}$ & & $N B$ \\
\hline 15 & Purcabises & $\mathrm{NB}$ & $\mathrm{N}$ & & $\mathrm{NB}$ & $\mathrm{NB}$ & $\mathrm{BB}$ & is & & B & $\mathrm{AB}$ & B & $\mathrm{NB}$ & & B \\
\hline $1 \frac{16}{17}$ & Trainnoiava & 50 & $\sqrt{7}$ & & B & $\sqrt{3}$ & $\sqrt{n}$ & R & 8 & $\begin{array}{c}\bar{B} \\
B\end{array}$ & R & 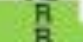 & $\frac{17}{8}$ & & 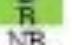 \\
\hline 18 & Salnova & & $\sqrt{3}$ & & 员 & 贵 & $\frac{0}{n}$ & 100 & & $\sqrt{\mathrm{B}}$ & $\stackrel{D}{R}$ & R & $\sqrt{n}$ & & $\frac{10}{N}$ \\
\hline 19 & Jatiwaras & $\mathrm{NB}$ & $\mathrm{B}$ & B & B & $\mathrm{NB}$ & $B$ & $B$ & NB & $\mathrm{AB}$ & $\mathrm{B}$ & $B$ & $\mathrm{NB}$ & B & $\mathrm{B}$ \\
\hline 20 & $\begin{array}{l}\text { Cimeam } \\
\text { Karampis }\end{array}$ & NB & $\frac{\mathrm{B}}{\mathrm{R}}$ & & & $\mathrm{NB}$ & B & $\frac{B}{B}$ & & $\mathrm{~B}$ & B & $\mathrm{MB}$ & $\mathrm{N}$ & & $\mathrm{NB}$ \\
\hline 22 & Masonizva & 8 & 13 & & $\mathrm{NB}$ & $\mathrm{NB}$ & $\mathrm{NB}$ & $\mathbb{N B}$ & & B & $B$ & B & B & B & $\mathrm{NB}$ \\
\hline 23 & Cnemmotanirme & $\overline{\mathrm{A}}$ & & & 霞 & $\sqrt{n}$ & $\bar{R}$ & 啇 & $\sqrt{8}$ & NM & $\sqrt{\mathrm{N}}$ & $\sqrt{\mathrm{N}}$ & Nh & $\bar{B}$ & $\sqrt{k}$ \\
\hline$\frac{24}{25}$ & Sinrananua & 夏 & $\mathrm{NB}$ & $\frac{1 B}{B}$ & $\mathrm{NB}$ & $\mathrm{NB}$ & $\frac{\mathrm{B}}{\mathrm{B}}$ & $\frac{\mathrm{NB}}{\mathrm{NB}}$ & NB & $\mathrm{NB}$ & $\mathrm{NB}$ & $\mathrm{NB}$ & $\mathrm{NB}$ & $\frac{B}{B}$ & $\frac{\mathrm{AB}}{\mathrm{B}}$ \\
\hline 26 & Mamsimena & R & $\mathrm{N}$ & 7 in & W & 㖞 & T & 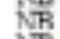 & & $\mathrm{N} M$ & NR & 宸 & NA & B & 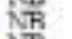 \\
\hline $2 ?$ & Ciraloetans & $\frac{8}{8}$ & $\mathrm{NB}$ & $\frac{N B}{7}$ & NB & $\mathrm{NB}$ & $\mathrm{NB}$ & $\frac{N_{R}}{N}$ & $\mathrm{NB}$ & $\mathrm{NB}$ & $\frac{N B}{R}$ & NB & $\frac{N B}{R}$ & $\frac{B}{R}$ & $\frac{N B}{R}$ \\
\hline 29 & Sariveseai & 尚 & $\mathrm{NB}$ & $\mathrm{B}$ & $\mathrm{N}$ & $\mathrm{NB}$ & $\mathrm{N}$ & N & & $\mathrm{NB}$ & $\mathrm{N}$ & $\mathrm{NB}$ & $\mathrm{N}$ & $\mathrm{B}$ & $\mathrm{NB}$ \\
\hline 30 & Padakembane & $\frac{B}{R}$ & $\frac{13}{7}$ & 13 & $\mathbb{N B}$ & $\mathrm{NB}$ & $\mathrm{NB}$ & $\mathrm{NB}$ & $\mathrm{NB}$ & $\frac{13}{7}$ & $\mathrm{NB}$ & $\mathrm{NB}$ & $\mathrm{NB}$ & $\frac{\mathrm{B}}{\mathrm{B}}$ & $\mathrm{B}$ \\
\hline 32 & Cisavenz & ह & $\mathrm{NB}$ & $\mathrm{MB}$ & $\mathrm{NB}$ & $\mathrm{NB}$ & $\mathrm{NB}$ & $\mathrm{NB}$ & $B$ & B & $\mathrm{NB}$ & $\mathrm{NB}$ & $\mathrm{NB}$ & $\mathrm{NB}$ & $\mathrm{NB}$ \\
\hline 76 & Sinkshanieg & 8. & $\sqrt{7}$ & & Nh & $\sqrt{3}$ & 10 & $\sqrt{R}$ & & $\stackrel{R}{R}$ & $\mathrm{~N} R$ & 党 & N & $N$ & $R$ \\
\hline 34 & Ravoolah & B & $\mathrm{NB}$ & B & $\mathrm{NB}$ & B & B & NB & NB & B & $\mathrm{NB}$ & NB & $\mathrm{NB}$ & B & $\mathrm{NB}$ \\
\hline 35 & Jamanis & 量 & $\frac{3}{3}$ & $5 \overline{7}$ & $\mathrm{NB}$ & $\stackrel{B}{17}$ & $\mathrm{AB}$ & $\frac{N B}{R}$ & $2 \mathrm{~B}$ & $\mathrm{AB}$ & $\mathrm{NB}$ & $\mathrm{NB}$ & $\frac{N B}{N B}$ & $\mathrm{AB}$ & $\frac{B}{3}$ \\
\hline 3 & Radivatom & NB & $\mathrm{N}, \mathrm{n}$ & B & $\mathrm{NB}$ & $\mathrm{NB}$ & $\mathrm{N} B \mathrm{~B}$ & N & $B$ & $\mathrm{~N} B$ & $\mathrm{NB}$ & $\mathrm{B}$ & $\mathrm{NB}$ & $B$ & 青 \\
\hline \multirow{3}{*}{39} & Prow & 5 & & & Nis & $\mathrm{N}$ & $\bar{B}$ & $\sqrt{8}$ & NA & N⿳⺈⿴囗十⺝ & N⿳⺈ & N & NA & & $\mathrm{NR}$ \\
\hline & Sularen? & $B$ & $\mathrm{NB}$ & B & $\mathrm{NB}$ & B & $B$ & B & NB & 13 & $\mathrm{NB}$ & $\mathrm{NB}$ & $\mathrm{NB}$ & $\sqrt{B}$ & $\mathrm{NB}$ \\
\hline & Total Basis & 22 & 11 & 13 & 8 & 8 & 11 & 10 & 11 & 14 & 10 & 14 & 8 & 13 & 10 \\
\hline
\end{tabular}




\section{Jurnal Agristan}

Vol. 3 No. 2 - November 2021

Halaman $149-171$

Tabel 2. Komoditas (lanjutan)

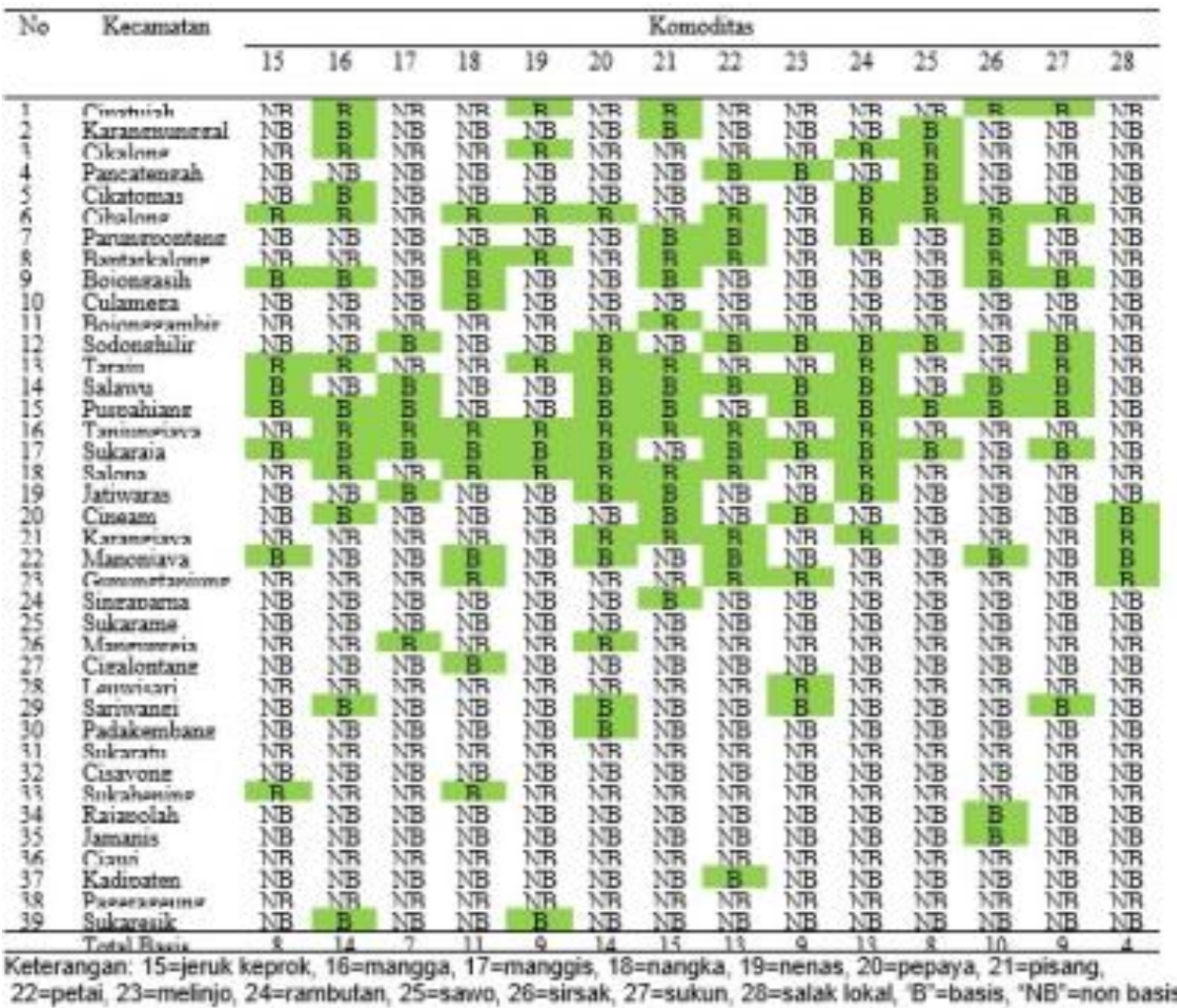

Tabel 2. Komoditas ..... (lanjutan)

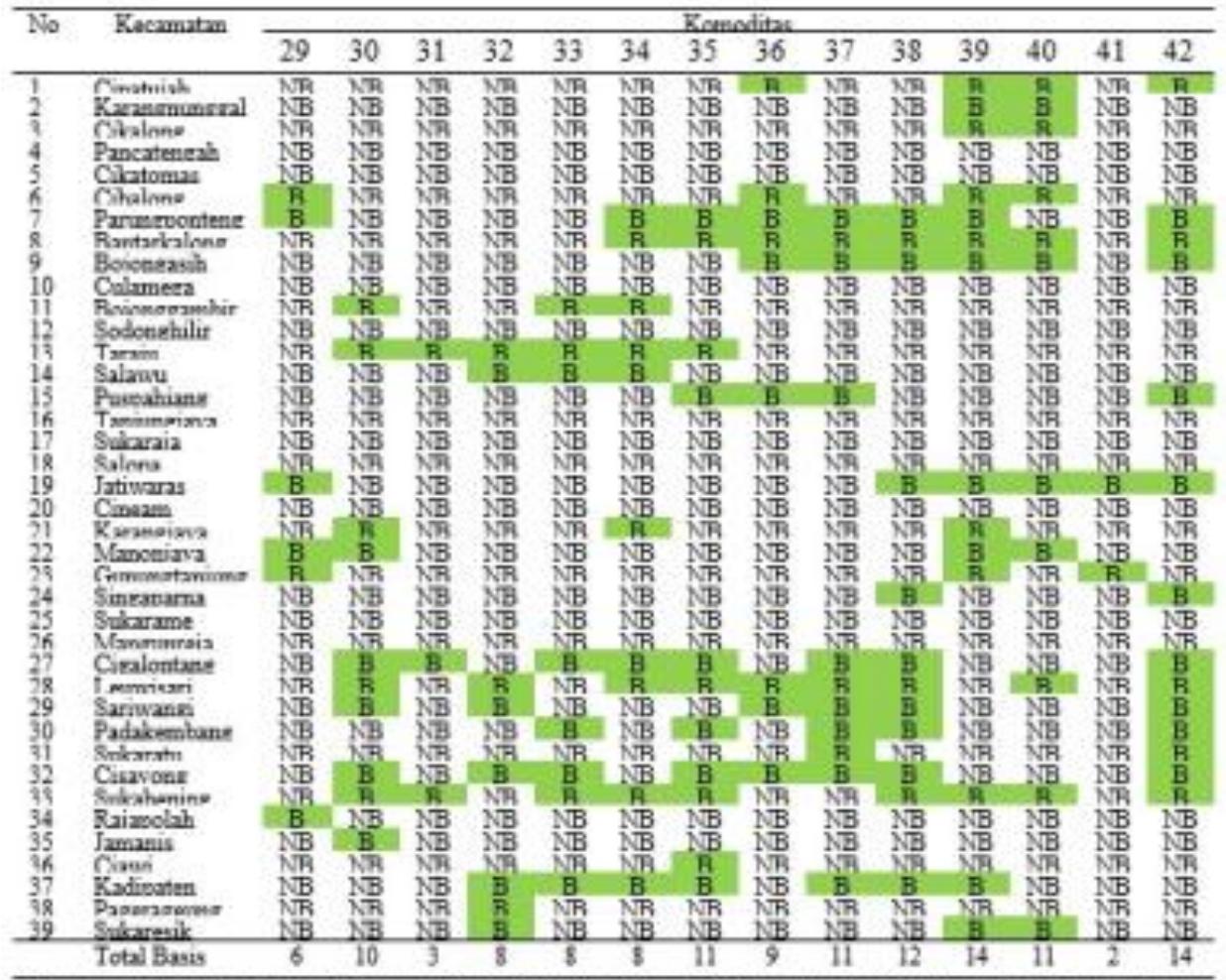

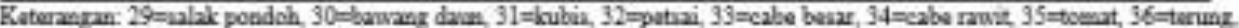

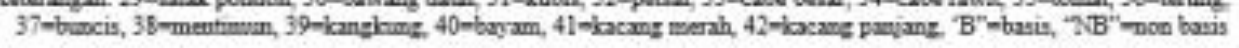




\section{PENENTUAN KOMODITAS UNGGULAN SUB SEKTOR TANAMAN PANGAN DAN HORTIKULTURA DI SETIAP KECAMATAN KABUPATEN TASIKMALAYA \\ Yayu Setiani, Unang dan Betty Rofatin}

sehingga di Kecamatan Cibalong banyak ditanami padi sawah dan tanaman hortikultura.

Kecamatan yang paling sedikit memiliki komoditas basis yaitu Kecamatan Sukara-me. Kecamatan tersebut relatif sedikit memiliki komoditas basis karena luas penggunaan lahan yang digunakan untuk kegiatan sebagian besar digunakan komodi-tas tanaman pangan yaitu padi dan bangunan/pekarangan.

Luas lahan yang ditanami padi sawah $998 \mathrm{Ha}(43,3$ \%) sedangkan luas bangunan/ pekarangan1.076,57 $\mathrm{Ha}$ $(46,8 \%)$ luas lahan sisanya untuk penggunaan lain (BPS Kabupaten Tasikmalaya, 2018)

Komoditas yang paling banyak menjadi basis pada sebagian besar kecamatan di Kabupaten Tasikmalaya pada tahun 2016-2020 dari masingmasing kelompok komoditas yaitu :

a. Tanaman pangan : padi

b. Tanaman buah-buahan : pisang

c. Tanaman sayuran : kangkung dan kacang panjang

Berdasarkan nilai LQ, komoditas tanam-an pangan yang menjadi basis sebagian besar kecamatan di Kabupaten Tasikmalaya yaitu padi. Komoditas padi menjadi basis di 22 kecamatan di Kabupaten Tasikmalaya, yaitu di Kecamatan Cikalong, Culamega,
Bojonggambir, Sodonghilir, Salopa, Manon-jaya, Gunungtanjung, Singaparna, Sukarame, Mangunreja, Cigalontang, Leuwisari, Sariwangi, Padakembang, Sukaratu, Cisa-yong, Sukahening, Rajapolah, Jamanis, Ciawi, Pagerageung, dan Sukaresik. Artinya kecamatan-kecamatan tersebut sudah dapat memenuhi kebutuhannya sendiri dan bahkan dapat memenuhi kebutuhan diluar wilayah kecamatan bersangkutan. Upaya pemerintah dalam peningkatan produksi tanaman pangan melalui program UPSUS PAJALE (Upaya Khusus Padi, Jagung, dan Kedelai) nampaknya cukup berhasil. Selain itu juga didukung oleh kondisi lingkungan yang cocok. Kecamatan-kecamatan tersebut cocok untuk pengembangan padi, hal ini sesuai sebagaimana dijelaskan oleh Cybex Pertanian bahwa tanaman padi dapat ditanam pada dataran rendah sampai dengan ketinggian $1.000 \mathrm{mdpl}$ sesuai dengan jenis varietas yang digunakan

Komoditas tanaman buah-buahan yang paling banyak menjadi basis yaitu komoditas pisang yang ada di 15 kecamatan yaitu Kecamatan Cipatujah, Karangnunggal, Parungponteng, Bantarkalong, Bojongasih, Bojonggambir, Taraju, Salawu, Puspahiang, Tanjungjaya, Salopa, Jatiwaras, Cineam, Karangjaya, dan Singaparna. Komoditas pisang banyak menjadi basis karena 
banyak masyarakat yang menanam pohon pisang. Selain itu juga didukung oleh kondisi lingkungan yang cocok. Kecamatan-kecamatan tersebut cocok untuk pengembangan pisang karena memiliki ketinggian wilayah 0-1.000 mdpl. Hal ini sebagaimana dijelaskan oleh Cybex Pertanian (2019) bahwa tanaman pisang bisa tumbuh di dataran rendah sampai ketinggian 2.000 mdpl. Namun paling cocok ditanam pada ketinggian $1.000 \mathrm{mdpl}$. Iklim tropis basah, lembab dan panas mendukung pertumbuhan pisang.

Komoditas tanaman sayuran yang paling banyak menjadi basis yaitu komoditas kangkung dan kacang panjang yang masing-masing komoditas ada di 14 kecamatan di Kabupaten Tasikmalaya. Untuk komoditas kangkung ada di Kecamatan Cipatujah, Karangnunggal, Cikalong, Cibalong, Parungponteng, Bantarkalong, Bojongasih, Jatiwaras, Karangjaya, Manonjaya, Gunungtanjung, Sukahening, Kadipaten, dan Sukaresik. Tanaman kangkung menjadi salah satu tanaman sayuran yang paling banyak menjadi basis dikarenakan tanaman kangkung yang sangat mudah ditanam, memiliki daya penyesuaian (adaptasi) yang luas terhadap berbagai keadaan lingkungan tumbuh, mudah dalam pemeliharaannya dan modal terjangkau dalam penyediaan biaya usahataninya sehingga tanaman kangkung menjadi primadona bagi kalangan masyarakat pada umumnya.

Kemudian selanjutnya tanaman kacang panjang menjadi tanaman sayuran yang paling banyak menjadi basis. Hal tersebut didukung oleh kondisi lingkungan yang cocok untuk pengembangan komoditas kacang panjang. Kecamatan-kecamatan tersebut cocok untuk pengembangan kacang panjang karena memiliki ketinggian wilayah 0-1.000 mdpl, hal ini sesuai dengan yang dijelaskan oleh Cybex Pertanian (2019) bahwa kacang panjang dapat tumbuh pada dataran rendah maupun dataran tinggi dengan ketinggian 0-1.500 mdpl. Kacang panjang dapat ditanam sepanjang musim baik musim kemarau maupun musim penghujan.

\section{B. Penentuan Prioritas Pengambangan Komoditas \\ Prioritas pengembangan komoditas} sub sektor tanaman pangan dan hortikultura basis masing-masing wilayah kecamatan di Kabupaten Tasikmalaya berdasarkan analisis LQ, PP dan PPW, dapat diketahui dengan melihat Tabel 3. Komoditas basis apa saja yang menempati prioritas utama, kedua dan ketiga atau alternatif.

Adapun komoditas yang paling banyak menjadi prioritas utama pada sebagian besar kecamatan di Kabupaten Tasikmalaya pada tahun 2016-2020 dari masing-masing kelompok komoditas yaitu : 


\section{PENENTUAN KOMODITAS UNGGULAN SUB SEKTOR TANAMAN PANGAN DAN HORTIKULTURA DI SETIAP KECAMATAN KABUPATEN TASIKMALAYA}

Yayu Setiani, Unang dan Betty Rofatin

- Tanaman pangan : padi

- Tanaman buah-buahan : belimbing, durian, mangga dan pepaya

Tabel 3. Prioritas Pengembangan Komoditas Sub Sektor Tanaman Pangan dan Hortikultura di Setiap Kecamatan

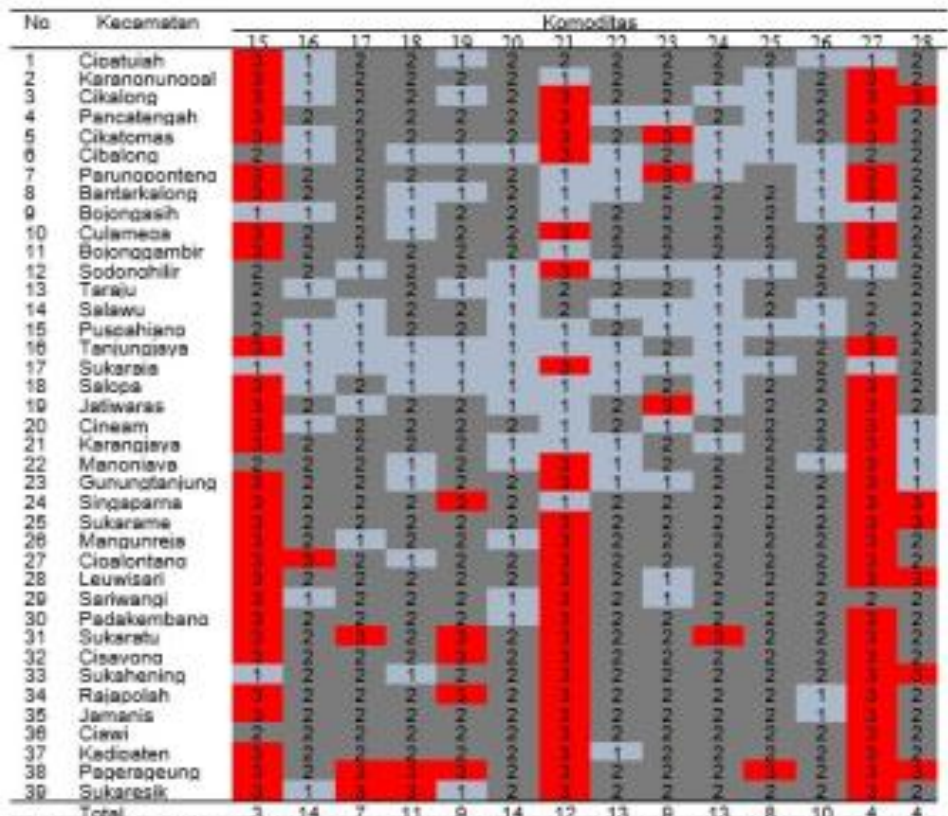

Keterangan: 15-jeruk keprok, 16-mangga, 17-manggis, 18-nangka, 19-nenas, 20-pepaya,

21 =pisang. 22 -petai, 23 =melinjo, $24=$ rambutan, $25=$ sawo, $26=$ sirsak, $27=$ sukun, $28=$ salak lokal - Prioritas 1 $=$ Prieritas 3 atma altumatif Priscitas 2

Tabel 3 Prioritas Pengembangan... (lanjutan)

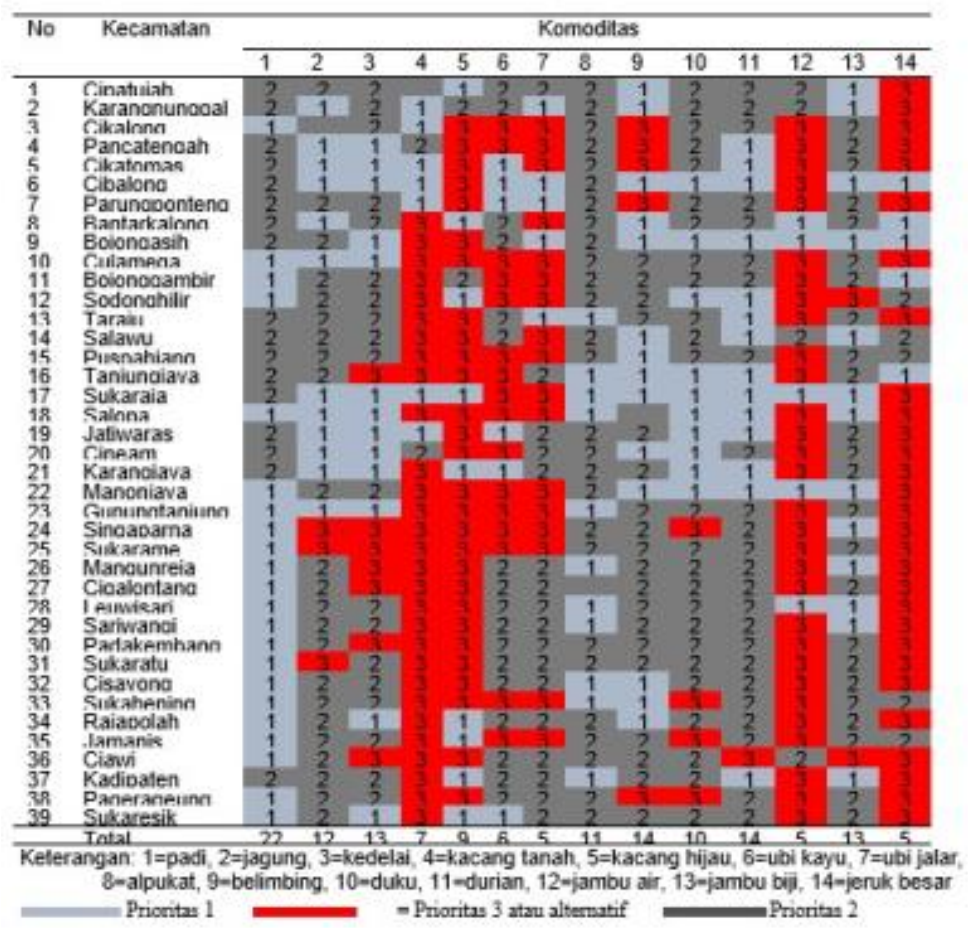


Tabel 3 Prioritas Pengembangan... (lanjutan)

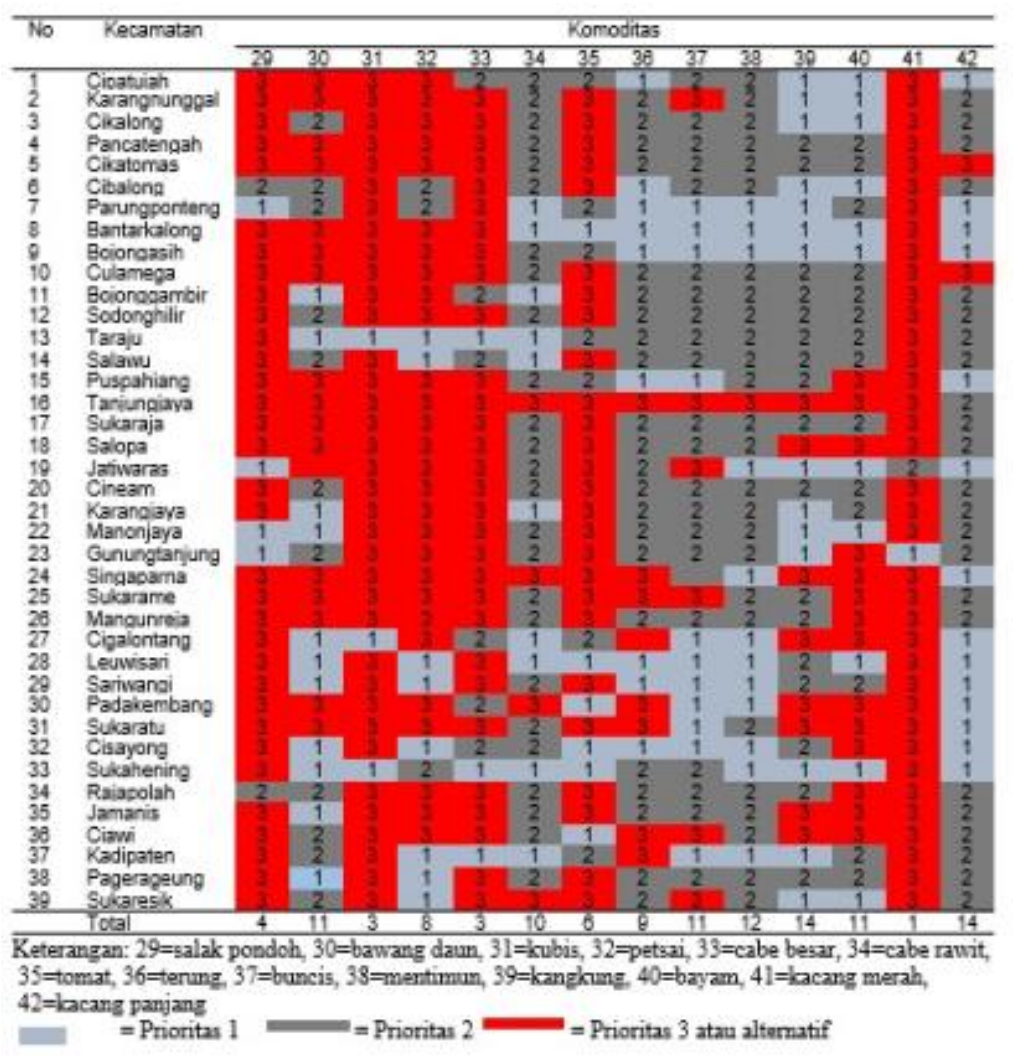

Berdasarkan hasil analisis yang di tampilkan pada Tabel 3, masing-masing Kecamatan mempunyai peluang dan kesempatan yang sama untuk mengembangkan komoditas sub sektor tanaman pangan dan hortikultura basis dan unggulan yang sesuai dengan kondisi alam dan daerah masing-masing Kecamatan. Pengembangan komoditas bagi Kecamatan yang memiliki lebih dari satu jenis komoditas perlu mempertimbangkan aspek-aspek lain yang juga dimiliki oleh Kecamatan lainnya seperti kemudahan akses pasar maupun sarana dan prasarana produksi pertanian.
Besarnya nilai Pertumbuhan Pangsa Wilayah (PPW) menunjukkan adanya keuntungan lokasional di wilayah kecamatan tersebut sehingga nilai PPW dapat digunakan sebagai bahan pertimbangan dalam pengembilan keputusan. PPW yang bernilai tinggi pada suatu komoditas tanaman pangan dan hortikultura basis berarti kecamatan tersebut akan mempunyai keuntungan faktor lokasional intern yang lebih tinggi dibandingkan dengan kecamatan lainnya sehingga kecamatan tersebut mempunyai daya saing wilayah yang lebih baik. 


\section{PENENTUAN KOMODITAS UNGGULAN SUB SEKTOR TANAMAN PANGAN DAN HORTIKULTURA DI SETIAP KECAMATAN KABUPATEN TASIKMALAYA}

Yayu Setiani, Unang dan Betty Rofatin

Komoditas yang paling banyak menjadi prioritas yang utama adalah komoditas padi yang terdapat di 22 Kecamatan, yaitu Kecamatan Cikalong, Culamega, Bojong-gambir, Sodonghilir, Salopa, Manonjaya, Gunungtajnjung, Singaparna, Sukarame, Mangunreja, Cigalontang, Leuwisari, Sariwangi, Padakembang, Sukaratu, Cisayong, Sukahening, Rajapolah, Jamanis, Ciawi, Pagerageung dan Sukaresik. Prioritas ini sesuai dengan yang diprioritaskan oleh Pemerintah Kabupaten Tasikmalaya. Luas lahan sekitar $19.000 \mathrm{Ha}$ akan dijadikan lahan pertanian berkelanjutan yaitu sawah abadi atau Kawasan Pertanian Pangan Berkelanjutan dalam RT RW Kabupaten Tasikmalaya. Diharapkan dengan adanya peraturan tersebut produksi akan meningkat.

Berdasarkan Tabel 3 komoditas sub sektor tanaman pangan dan hortikultura yang banyak menjadi prioritas kedua adalah manggis, sawo dan salak lokal yang terdapat di 29 Kecamatan yaitu untuk manggis ada di Kecamatan Cipatujah, Karangnunggal, Cikalong, Pancatengah, Cikatomas, Cibalong, Parungponteng, Bantarkalong, Bojongasih, Culamega, Bojonggambir, Taraju, Salopa, Cineam, Karangjaya, Manonjaya, Gunung-tanjung, Singaparna, Sukarame, Cigalon-tang, Leuwisari, Sari-wangi, Padakembang, Cisayong, Sukahening, Rajapolah,
Jamanis, Ciawi, dan Kadipaten. Sawo ada di Kecama-tan Cipatujah, Parungponteng, Bantarka-long, Bojongasih, Culamega, Bojonggambir, Taraju, Salawu, Salopa, Jatiwaras, Cineam, Karangjaya, Manonjaya, Gunungtanjung, Singaparna, Sukarame, Mangunreja, Ciga-lontang, Lauwisari, Sariwangi, Padakem-bang, Sukaratu, Cisayong, Sukahening, Rajapolah, Ciawi, Kadipaten, Pagerageung, dan Sukaresik. Salak lokal ada di Kecamatan Cipatujah, Karang-nunggal, Pancatengah, Cikatomas, Cibalong, Parungponteng, Bantarkalong, Bojong-asih, Culamega, Bojonggambir, Sodonghilir, Taraju, Salawu, Puspahiang, Tanjungjaya, Sukaraja, Salopa, Jatiwaras, Mangunreja, Cigalontang, Sariwangi, Sukaratu, Cisayong, Rajapolah, Jamanis, Ciawi, Kadipaten dan Sukaresik. Komoditas yang paling sedikit menjadi prioritas kedua pada masing-masing Kecamatan adalah kubis yang terdapat di satu Kecamatan yaitu Kecamatan Taraju.

Kecamatan yang paling banyak memiliki Komoditas sub sektor tanaman pangan dan hortikultura yang menjadi prioritas kedua adalah Kecamatan Bojonggambir sebanyak 26 Komoditas (alpukat, belimbing, duku, durian, jambu biji, mangga, manggis, nangka, nenas, pepaya, petai, rambutan, sawo, sirsak, melinjo, salak lokal, jagung, kedelai, kacang hijau, bayam, cabe besar, terung, 
buncis, mentimun, kangkung, kacang panjang). Sedangkan Kecamatan yang paling sedikit memiliki komoditas sub sektor tanaman bahan makanan prioritas kedua adalah Kecamatan Sukaraja sebanyak 11 komoditas (pepaya, sirsak, salak lokal, padi, cabe rawit, terung, buncis, mentimun, kangkung, bayam, kacang panjang).

Berdasarkan Tabel 3 komoditas yang paling banyak menjadi prioritas ketiga adalah komoditas kubis yang terdapat di 36 Kecamatan. Sedangkan komoditas yang sedikit menjadi prioritas ketiga adalah padi, mentimun, rambutan dan sawo yang hanya ada di satu Kecamatan. Padi hanya ada di Kecamatan Parungponteng, mentimun hanya ada di Kecamatan Manonjaya, rambutan hanya ada di Kecamatan Suka-ratu, dan sawo hanya ada di Kecamatan Pagerageung. Komoditas yang tidak termasuk kedalam prioritas pengembangan ketiga adalah alpukat, durian, jambu biji, pepaya, petai, sirsak dan kacang panjang.

Kecamatan yang paling banyak memiliki komoditas dengan prioritas ketiga adalah Kecamatan Singaparna dengan 24 komoditas (jambu air, jeruk besar, jeruk keprok, sukun, duku, nenas, salak lokal, salak pondoh, jagung, kedelai, kacang tanah, kacang hijau, ubi kayu, ubi jalar, bawang daun, kubis, cabe besar, cabe rawit, terung, kangkung, bayam, petsai, tomat, kacang merah).
Sedangkan Kecamatan yang memiliki sedikit komoditas dengan prioritas ketiga yaitu Kecamatan Taraju dan Salawu dengan masing-masing Kecamatan enam komoditas. Kecamatan Karang-nunggal yaitu jeruk besar, jeruk keprok, sukun, salak pondoh, bawang daun, kubis, buncis, tomat, petsai, kacang merah, kacang hijau, cabe besar. Kecamatan Salawu yaitu salak pondoh, kacang tanah, kacang hijau, bayam, tomat, kubis.

Berdasarkan hasil di atas, masingmasing kecamatan mempunyai peluang dan kesempatan untuk mengembangkan komo-ditas tanaman pangan dan hortikultura yang sesuai dengan kondisi masing-masing kecamatan.

Pengembangan komoditas bagi kecamatan yang memiliki lebih dari satu jenis komoditas yang masuk kedalam prioritas pengembangan utama perlu mempertimbangkan kembali aspekaspek lain yang juga dimiliki oleh kecamatan lainnya seperti fasilitas sarana dan prasarana produksi pertanian juga kemudahan dalam akses pasar.

Kriteria yang digunakan dalam hasil penelitian prioritas pengembangan komodi-tas tanaman pangan dan hortikultura adalah menghitung nilai produksi dari masing-masing komoditas tanaman pangan dan hortikultura yang kemudian diidentifikasi dan dianalisis menggunakan pendekatan gabungan $L Q$ dan Shift Share (PP dan PPW) masing- 


\section{PENENTUAN KOMODITAS UNGGULAN SUB SEKTOR TANAMAN PANGAN DAN HORTIKULTURA DI SETIAP KECAMATAN KABUPATEN TASIKMALAYA \\ Yayu Setiani, Unang dan Betty Rofatin}

masing komoditas tanaman pangan dan hortikultura basis.

Informasi mengenai prioritas pengem-bangan komoditas tanaman pangan dan hortikultura masing-masing kecamatan di Kabupaten Tasikmalaya dapat memberikan kontribusi dalam pertimbangan pengambilan kebijakan perencanaan pembangunan wilayah Kabupaten Tasikmalaya, khususnya dalam pemetaan dan penentuan komoditas tanaman pangan dan hortikultura basis yang menjadi prioritas pengembangan masing-masing kecamatan sehingga diharapkan Pemerintah Daerah Kabupaten Tasikmalaya dapat mengoptimalkan sektor pertanian daerah dengan mengacu pada potensi daerah yang dimiliki dan komoditas tanaman pangan dan hortikultura basis yang diprioritaskan untuk dikembangkan pada masingmasing kecamatan di Kabupaten Tasikmalaya.

C. Identifikasi Komoditas Unggulan di Setiap Kecamatan

Potensi pengembangan berbagai komo-ditas pada sub sektor tanaman pangan dan hortikultura di beberapa kecamatan secara keseluruhan mempunyai keunggulan serta potensinya masing-masing yang memung-kinkan untuk terus dikembangkan guna meningkatkan pertumbuhan ekonomi. Peningkatan produksi pada berbagai komoditas tanaman pangan dan hortikultura merupakan salah satu langkah dalam upaya pencapaian target yang direncanakan sebelumnya.

Komoditas sub sektor tanaman pangan dan hortikultura yang menjadi komoditas unggulan adalah komoditas yang memiliki pertumbuhan yang cepat dan berdaya saing baik jika dibandingkan dengan komoditas yang sama di kecamatan lain di Kabupaten Tasikmalaya. Dikatakan memiliki pertumbuhan yang cepat jika ditunjukkan dengan nilai PP yang bernilai positif dan dikatakan memiliki daya saing yang baik jika ditunjuk-kan dengan PPW yang bernilai positif. Peran dari masing-masing komoditas pada sub sektor tanaman pangan dan hortikultura akan mampu memberikan dampak positif bagi peningkatan sektor pertanian di kecamatan tersebut. Adanya penentuan komoditas yang menjadi unggulan atau diunggulkan akan memudahkan pemerintah dalam penentuan kebijakan terkait pengem-bangan sub sektor tanaman pangan dan hortikultura khususnya pada masing-masing kecamatan agar pembangunan yang dilakukan dapat tepat sasaran sehingga proses dalam merealisasikan pembangunan melalui peningkatan ekonomi dapat maksimal dan sesuai dengan sumber daya yang dimiliki.

Hasil analisis komoditas unggulan sub sektor tanaman pangan dan 
hortikultura di wilayah masing-masing Kecamatan Kabupaten Tasikmalaya tahun 2016-2020 ditampilkan pada Tabel 4. Berdasarkan Tabel 4 tersebut dari masing-ma-sing kelompok komoditas yaitu :

- Tanaman pangan : padi

- Tanaman buah-buahan : jambu biji, dan nangka

- Tanaman sayuran : mentimun

Menurut Widodo (2007) terdapat dua faktor utama yang perlu diperhatikan dalam mengidentifikasi potensi kegiatankegiatan ekonomi daerah. Pertama, sektor ekonomi yang unggul atau mempunyai daya saing dalam beberapa periode tahun terakhir dan kemungkinan prospek sektor ekonomi dimasa datang. Kedua, sektor ekonomi yang potensial untuk dikembangkan di masa mendatang, walaupun pada saat ini belum mempunyai tingkat daya saing yang baik.

Sebagaimana dikatakan oleh Wahyudi (2017) kunci utama untuk mencapai kinerja pembangunan daerah yang bagus dan berkelanjutan pada era otonomi dan globalisasi ekonomi adalah daya saing. Tingkat daya saing merupakan salah satu parameter dalam pembangunan daerah kabupaten/kota, maka dari itu komoditas unggulan tentu harus memiliki daya saing.

Pengembangan komoditas yang memiliki keunggulan spesifik wilayah akan menciptakan ruang yang kondusif dalam pengembangan pertanian berkelanjutan. Komoditas unggulan yaitu komoditas yang memberikan sumbangan terbesar dalam perekonomian dan pertumbuhan wilayah. Identifikasi komoditas unggulan penting dilakukan misalnya dalam kerangka menyusun road map pengembangan agar komoditas tersebut dapat terus tumbuh dan berkembang sebagai komoditas andalan wilayah (Zainal Abidin, 2018).

Data komoditas sub sektor tanaman pangan dan hortikultura basis pada masing-masing Kecamatan di Kabupaten Tasikmala-ya tahun 2016-2020 berdasarkan hasil analisis LQ rata-rata pada Tabel 2 menun-jukkan bahwa komoditas sub sektor tanam-an pangan dan hortikultura basis telah teridentifikasi. Jenis-jenis komoditas sub sektor tanaman pangan dan hortikultura tersebut tersebar di masing-masing wilayah kecamatan di Kabupaten Tasikmalaya dan beberapa jenis dari komoditas tersebut terdapat di beberapa sentra produksi. Produksinya pun memang lebih tinggi dibandingkan dengan tempat lainnya. 


\section{PENENTUAN KOMODITAS UNGGULAN SUB SEKTOR TANAMAN PANGAN DAN HORTIKULTURA DI SETIAP KECAMATAN KABUPATEN TASIKMALAYA}

Yayu Setiani, Unang dan Betty Rofatin

Tabel 4. Komoditas Unggulan Sub Sektor Tanaman Pangan dan Hortikultura di Setiap Kecamatan di Kab. Tasikmalaya(2016-2020)

\begin{tabular}{|c|c|c|c|c|c|c|c|c|c|c|c|c|c|c|c|}
\hline \multirow[t]{2}{*}{$\sqrt{6}$} & Kects & \\
\hline & & & & & & & & & & & & & & & \\
\hline & $\begin{array}{l}\text { Cpaniah } \\
\text { Karanonunosal }\end{array}$ & 照 & 斟 & 䀝 & $\begin{array}{l}\mathrm{y}^{\circ} \\
\text { 时 }\end{array}$ & $\mathcal{U U}_{\mathrm{BU}}$ & 西 & EU & B. & Bu & gu & $\begin{array}{l}\mathrm{gu} \\
\mathrm{Bu}\end{array}$ & $\begin{array}{l}\mathrm{gu} \\
\mathrm{Bu}\end{array}$ & gu & 而 \\
\hline & chalome & อับ & हิ & घU & 政 & BU & BU & ถูบ & Bu & Bu & ถับ & हu & हu & gu & हू \\
\hline & then & Bu & u & u & gu & BU & $\mathrm{BU}$ & B & Bu & gu & Bu & Bu & Bu & Bu & Bu \\
\hline & Parune: & Bu & Bu & BU & Gu & Bu & $\mathrm{BU}$ & B & Bu & u & Bu & 淂 & BU & BU & iv \\
\hline & Bartarkat: & ดบ & u & 80 & Bu & QU & Bu & F & $B U$ & Iu & Bu & Bu & Bu & 䒜 & Bu \\
\hline & Culares: & $y$ & $u$ & 照 & 的 & BU & BU & 5 & Eu & gù & gu & gu & EU & Bu & . \\
\hline & not & & gu & BU & eu & Bu & gu & $E$ & gu & gu & 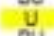 & au & 㩆 & Gu & u \\
\hline & & & gu & BU & BU & BU & BU & B. & BU & Bu & uv & & & Bu & 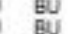 \\
\hline & Puspatiana & 淂 & Bu & 时 & 淂 & 是 & 时 & 照 & 㝵 & Bu & 时 & 时 & 星 & 造 & 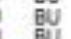 \\
\hline & s & Bu & BU & BU & EU & EU & EU & B & y & u & u & u & 甚 & u & EU \\
\hline & & Bu & Bu & Bu & 焉 & घบ & ${ }_{\mathrm{EU}}^{\mathrm{BU}}$ & Bu & B. & Bu & & & & BU & y \\
\hline & Gines & $\frac{1}{8}$ & u & ü & 昆 & 时 & 喅 & ติ & ถูบ๊ & gu & ถบ & Bu & gu & gu & aty \\
\hline & Manoria & & gu & Bu & gu & gu & $B U$ & $\mathrm{~B}$ & Bu & Bu & gu & $u$ & au & $u$ & 时 \\
\hline & 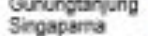 & BU & Bu & gU & 㯊 & Bu & bu & Ba & & Bu & Bu & & & & \\
\hline & $\begin{array}{l}\text { Sukarame } \\
\text { Mangintela }\end{array}$ & $i$ & 照 & 的 & 胞 & BU & 既 & Bu & Eบ & 的 & Bu & 时 & gu & हू & 期 \\
\hline & Coziontana & & gu & 斯 & 斯 & EU & EU & Bu & Bu & gu & gu & gu & Bu & Eu & 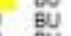 \\
\hline & $\begin{array}{l}\text { Leuvissa } \\
\text { Sariwan: }\end{array}$ & & 思 & 昆 & 昆 & ${ }_{\mathrm{BU}}^{\mathrm{BU}}$ & ${ }_{\mathrm{BU}}^{\mathrm{BU}}$ & $\mathrm{Bu}$ & Bu & ${ }_{\text {Gu }}^{\text {Gu }}$ & 80 & & & Bu & 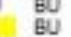 \\
\hline & $\begin{array}{l}\text { Padakembara } \\
\text { Sularaty }\end{array}$ & it & 淂 & BU & 淂 & 时 & BU & BU & Bu & Bu & Bบ & BU & Bu & aบ & 最 \\
\hline & 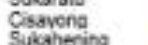 & & 暗 & Bu & 照 & 是 & 最 & BU & $\mathrm{BU}$ & Bu & Bu & 咩 & Ant & Bu & \\
\hline & $\begin{array}{l}\text { Sulathering } \\
\text { Rajusolah }\end{array}$ & 8 & 配 & U & $\begin{array}{l}\mathrm{Bu} \\
\mathrm{Bu}\end{array}$ & & & BU & Bu & u & $\mathrm{Bu}$ & 配 & $\mathrm{Bu}$ & EU & EU \\
\hline & $\begin{array}{l}\text { Jamania } \\
\text { cowe }\end{array}$ & An & 暍 & 照 & 鼠 & 昆 & BU & 鼠 & SU & gu & gu & gu & हบ & gu & 歇 \\
\hline & $\begin{array}{l}\text { Kadpatan } \\
\text { Paperageu }\end{array}$ & & Bd & 摬 & Ei & . & . & b & Bu & 时 & g & & & 时 & \\
\hline & & & & & & & & & & & & & & & \\
\hline & & & & & & & & & & & & & & & \\
\hline
\end{tabular}

Keterangan: 1mpadi, 2-jagung. 3-kedelai, 4-kacang tanah, 5-kacang hijau, 6-ubi kayu, 7-ubi jalar, $8=a i p u k a t, 9=b e i m b i n g, 10=d u k u, 11=d u r i a n, 12=j a m b u$ air, $13=j a m b u$ bij, $14=$ eruk besat.

"U"=unggulan, "BU'=bukan unggulan = Unggulan

Tabel 4. Komoditas Unggulan ... (lanjutan)

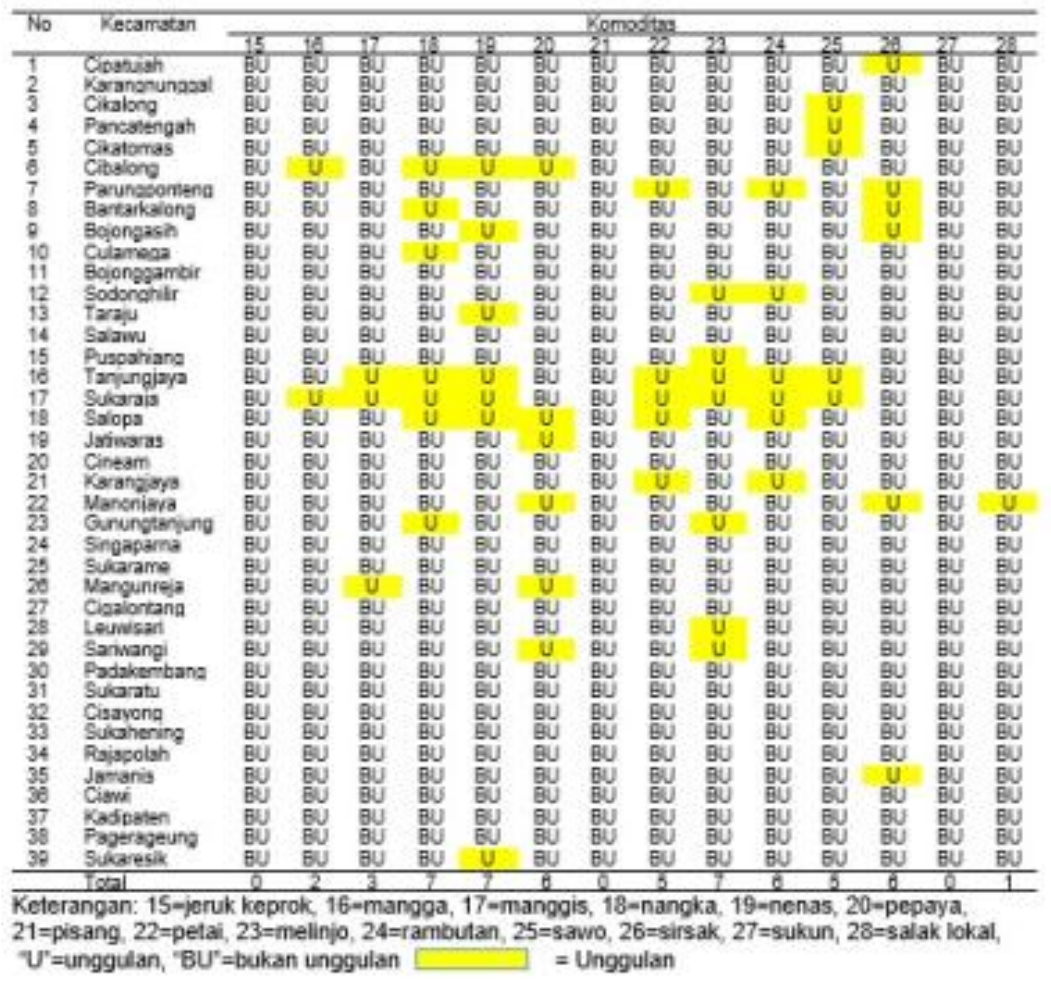


Tabel 4. Komoditas Unggulan ... (lanjutan)

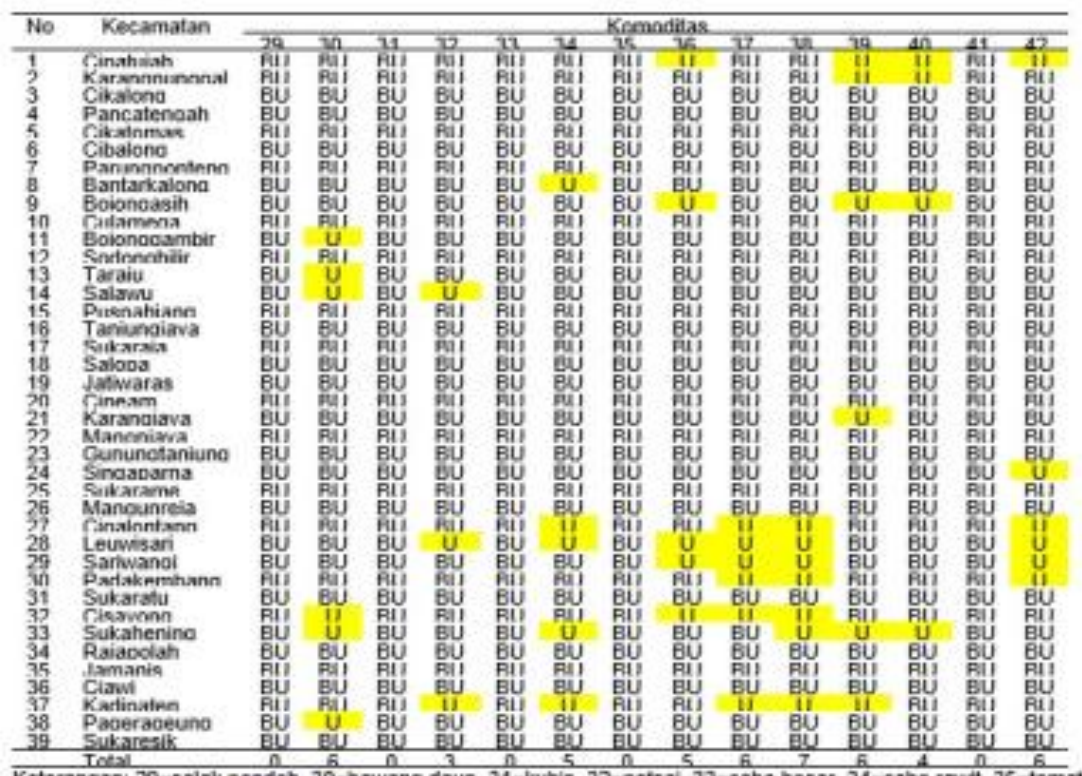

Keterangan: 29-salaik pondoh, 30-bawang daun, 31-kubis, 32-pefsai, 33-cabe besar, 34-cabe ravit, 35-tomat. 36-Jerung, 37-buncis, 30-mentmun, 39-kangkung, 40-bayam, 41-kacang merah, 42-kacang panjang, "U'-ungquian, eu'-bukan unggulan

Berdasarkan hasil penggabungan nilai $L Q>1$, komponen Pertumbuhan Proporsio-nal (PP) dan komponen Pertumbuhan Pangsa Wilayah (PPW), komoditas tanaman pangan yang paling banyak menjadi unggulan di wilayah kecamatan yaitu padi.

Komoditas padi dikatakan unggulan karena merupakan komoditas basis dengan pertumbuhan yang cepat dengan daya saing baik. Padi menjadi komoditas unggulan di 13 kecamatan, yaitu kecamatan Sodonghilir, Salopa, Manonjaya, Sukarame, Mangun-reja, Cigalontang, Sariwangi, Padakem-bang, Sukaratu, Cisayong, Sukahening, Ciawi, dan Sukaresik.
Padi merupakan tanaman penting bagi masyarakat Indonesia. Padi mempunyai nilai historis yang tinggi dan sejak lama menjadi makanan pokok utama bagi masyarakat Indonesia. Walaupun sumber karbohidrat tidak hanya pada padi tapi juga beberapa tanaman seperti jagung, sagu, aren, singkong, ketela rambat atau talas. Namun secara umum, padi tetap menjadi yang populer dan banyak diminati masyarakat Indonesia.

Program diversifikasi pangan sebagai upaya mengurangi konsumsi beras telah disusun pada 1980an. Tapi belum menunjukkan hasil yang memuaskan. Oleh sebab itu padi memang sangat penting bagi kehidupan 


\section{PENENTUAN KOMODITAS UNGGULAN SUB SEKTOR TANAMAN PANGAN DAN HORTIKULTURA DI SETIAP KECAMATAN KABUPATEN TASIKMALAYA \\ Yayu Setiani, Unang dan Betty Rofatin}

bangsa. Kabupaten Tasikmalaya merupakan salah satu daerah penghasil padi Jawa Barat.

Pada kelompok tanaman pangan, komoditas ubi kayu, ubi jalar, kacang hijau dan kacang tanah belum menjadi komoditas unggulan di Kabupaten Tasikmalaya, karena di sebagian besar wilayah kecamatan ubi kayu, ubi jalar, kacang hijau dan kacang tanah tidak memiliki daya saing yang baik meski memiliki pertumbuhan yang cepat dan bukan merupakan komoditas unggulan, akan tetapi komoditas ubi kayu, ubi jalar, kacang hijau dan kacang tanah diperlukan untuk memenuhi kebutuhan di wilayah Kabupaten Tasikmalaya, maka budidaya atau usaha pengembangan komoditas-komoditas tersebut tetap diperlukan.

Ubi kayu merupakan komoditas tanaman pangan terpenting ketiga setelah padi dan jagung. Peningkatan produksi ubi kayu akan lebih efektif jika ditempuh melalui peningkatan luas tanam. Namun pendekat-an luas tanam tersebut tidak efsisien bagi upaya peningkatan produksi tanaman pangan secara keseluruhan karena persaingan lahan usahatani dengan komoditas lainnya. Oleh karena itu, upaya peningkatan produksi ubi kayu sebaiknya lebih diutamakan melalui peningkatan produktivitas (Ening Ariningsih, 2016).
Menurut Dinas Pertanian Jawa Barat (2018) kawasan andalan agribisnis dan sentra produksi ubi jalar di Jawa Barat salah satu yang termasuk kedalamnya adalah Kabupaten Tasikmalaya. Ubi jalar diposisi-kan sebagai sumber karbohidrat utama setelah padi, jagung, kedelai, dan ubi kayu, serta mempunyai peranan penting dalam penyediaan bahan pangan, bahan baku industri maupun pakan ternak. Namun penggunaan ubi jalar di Indonesia masih terbatas pada bahan pangan tambahan dan bahan pengganti pada industri makanan (Nani Zuraida,2009). Usaha ubi jalar pada umumnya dilakukan secara komersial. Areal dan wilayah produksi yang relatif rendah tanpa fasilitas dan bantuan Pemerintah, mengindikasikan bahwa usahatani ubi jalar cukup kompetitif terhadap palawija lain dan menguntungkan secara ekonomis. Oleh sebab itu, perlu adanya peningkatan pengetahuan petani mengenai potensi dan peluang ubi jalar yang cukup besar untuk dimanfaatkan dalam agroindustri sekaligus diversifikasi pangan.

Upaya yang telah dilakukan Pemerintah dalam peningkatan produksi komoditas tanaman pangan yaitu pelaksanaan program Upaya Khusus Padi, Jagung, dan Kedelai (Upsus Pajale). Melaui program tersebut kebutuhan pangan khususnya beras dalam negeri sudah mampu tercukupi 
melalui produksi lokal. Semestinya pemerintah tidak perlu melakukan impor beras dari negara tetangga. Dengan dilanjutkannya program tersebut diharapkan kebutuhan pangan, khususnya di Kabupaten Tasikmalaya dapat terpenuhi melalui produksi lokal.

Komoditas jambu biji dan nangka menjadi komoditas dari tanaman buahbuahan yang paling banyak menjadi komoditas unggulan di Kabupaten Tasikma-laya karena merupakan komoditas basis dengan pertumbuhan yang cepat dan berdaya saing baik. Komoditas jambu biji dan nangka menjadi komoditas unggulan di 8 kecamatan. Sedangkan menurut Dinas Pertanian, Pangan dan Perikanan Kabupa-ten Tasikmalaya (2019) komoditas jambu biji dan nangka bukan merupakan komoditas unggulan. Data menujukkan Jamu biji dapat diunggulkan di 8 kecamatan dan nangka di 7 kecamatan. Komoditas jambu biji dan nangka merupakan komoditas yang ditanam masyarakat di pekarangan rumah sejak dahulu. Skala usaha atau skala kepemilikan yang kecil tanaman ini menjadi kurang efisien dibandingkan dengan budidaya komoditas lain. Itu lah yang membuat komoditas jambu biji dan nangka kalah bersaing terutama dalam hal ketersediaan produksi. Selain itu juga keterbatasan pengetahuan dan teknologi yang menghambat masyarakat atau petani untuk meningkat-kan skala budidaya nya, sehingga perlu adanya inovasi dalam pengolahan hasil produksi dan pengelolaan budidaya yang tepat sehingga mampu meningkatkan skala budidaya nya.

Komoditas manggis dikatakan komoditas unggulan karena merupakan komoditas basis dengan pertumbuhan cepat dan berdaya saing yang baik. Menurut Dinas Pertanian, Pangan dan Perikanan Kabupa-ten Tasikmalaya (2020) manggis juga merupakan salah satu komoditas unggulan di Kabupaten Tasikmalaya, bahkan menjadi komoditas buah unggulan Indonesia. Manggis menjadi komoditas unggulan di beberapa kecamatan yaitu Kecamatan Tanjungjaya, Sukaraja dan Mangunreja. Komoditas manggis sebagian berasal dari kebun rakyat yang belum terpelihara secara baik dan sistem produksinya masih bergan-tung pada alam (tradisional). Manggis berpotensi tumbuh di seluruh wilayah Indonesia, akan tetapi jumlah produksi manggis tiap daerah tidak sama dikarenakan keadaan alam serta topografisnya. Kabupaten Tasikmalaya adalah salah satu sentra manggis di Indonesia dengan total produksi pada tahun 2019 mencapai 43.272 ton (BPS Kabupaten Tasikmalaya 2020). Salah satu keunggulan dalam memperoduksi manggis di Kabupaten Tasikmalaya karena memiliki letak geografis yang cukup baik bagi 


\section{PENENTUAN KOMODITAS UNGGULAN SUB SEKTOR TANAMAN PANGAN DAN HORTIKULTURA DI SETIAP KECAMATAN KABUPATEN TASIKMALAYA}

Yayu Setiani, Unang dan Betty Rofatin

perkembangan komoditas dan didukung dengan sumber daya manusia yang cukup produktif.

Kecamatan Puspahiang selama ini dikenal sebagai sentra produksi manggis di Kabupaten Tasikmalaya. Namun dari hasil penelitian didapatkan manggis merupakan komoditas unggulan di tiga kecamatan yaitu Kecamatan Tanjungjaya, Sukaraja dan Mangunreja. Hal ini disebabkan karena tanaman manggis di Kecamatan Puspahiang, selama ini merupakan sentra penjualan manggis untuk diekspor. Sedang-kan produksinya sendiri sudah berkurang karena banyak pohon manggis yang sudah tua (lebih dari 70 tahunan). Sebagimana dilaporkan Nur Rahmawati dkk (2019) beberapa tanaman manggis di Puspahiang memiliki umur yang tua dan terdapat beberapa tanaman yang sudah tidak produktif maupun dan bahkan sudah mati. Oleh sebab itu, komoditas manggis di Kecamatan Puspahiang perlu peremajaan serta dibudidayakan baik secara teknis maupun secara ekonomis dengan tujuan meningkatkan produksi manggis.

Komoditas jambu air, jeruk besar, jeruk keprok, dan sukun belum menjadi komoditas unggulan di semua kecamatan. Menurut Dinas Pertanian, Pangan dan Perikanan Kabupaten Tasikmalaya (2020), komoditas jambu air, jeruk besar, jeruk keprok, dan sukun bukan merupakan komoditas unggul-an.

Komoditas mentimun menjadi komodi-tas dari tanaman sayuran yang paling banyak menjadi komoditas unggulan di Kabupaten Tasikmalaya karena merupakan komoditas basis dengan pertumbuhan yang cepat dan berdaya saing baik. Komoditas mentimun menjadi komoditas unggulan di 8 kecamatan. Luas area tanam secara keseluruhan di Kabupaten Tasikmalaya adalah 3.933 hektar. Peluang untuk lebih dikembangkan komoditas hortikultura sayuran lebih besar karena komoditas tersebut ditanam hampir di seluruh kecama-tan (Balittanah, 2021). Namun menurut Dinas Pertanian, Pangan dan Perikanan Kabupaten Tasikmalaya (2020), komoditas mentimun bukan merupakan komoditas unggulan.

Komoditas cabe besar, dan kacang merah menjadi komoditas unggulan di beberapa kecamatan yaitu di 7 kecamatan untuk cabe besar dan kacang merah di 6 kecamatan, dua komoditas tersebut memiliki daya saing yang baik. Sedangkan menurut Dinas Pertanian, Pangan dan Perikanan (2020), komoditas cabe besar merupakan komoditas unggulan di Kabupaten Tasikma-laya.

Menurut Balittanah

Kabupaten Tasikmalaya memiliki peluang lebih besar dalam pengembangan tanaman cabai karena kondisi alam yang 
cocok. Namun meskipun begitu, dari keseluruhan luas panen yang dilakukan, pemanenan cabai besar hijau lebih banyak yaitu sekitar $65 \%$ dari pada pemanenan cabai besar merah yang hanya sekitar $35 \%$ dari total panen. Harga cabai sangat berflutktuatif sekali tergantung musim dan permintaan pasar. Disamping itu, terdapat perbedaan harga yang signifikan antara cabai besar hijau dan cabai besar merah. Harga cabai dipanen merah biasanya jauh lebih mahal dibanding dengan harga cabai hijau, selain itu ketahanan cabai besar merah lebih baik daripada cabai besar hijau. Namun untuk melakukan pemanenan cabai besar merah memerlukan biaya tambahan dan resiko serangan hama atau penyakit (Dedi, 2016). Oleh sebab itu, perlu adanya pembinaan dan evaluasi terhadap sikap dan perilaku petani perlu terus dilakukan serta jaminan kepastian harga, agar dikemudian hari cabai besar benar-benar dapat menjadi komoditas yang unggulan.

Berdasarkan uraian di atas peran pemerintah daerah tampak cukup baik dalam pengembangan komoditaskomoditas tanaman pangan dan hortikultura di wilayah kecamatan di Kabupaten Tasikmalaya terutama pada komoditas tanaman pangan dan hortikultura yang sudah menjadi unggulan. Pemerintah Kabupaten Tasikma-laya perlu mempertahankan komoditas yang menjadi unggulan dengan melalui program-program yang telah ada. Sedangkan untuk komoditas tanaman pangan dan hortikultura yang belum menjadi unggulan perlu adanya perhatian khusus dalam peningkatan kualitas Sumber Daya Manusia (SDM) yang masih rendah. Salah satu caranya dengan adanya pemberdayaan bagi petani, baik melalui pendidikan dan juga pelatihan.

Pelatihan dapat berupa kegiatan penyuluhan yang lebih ditekankan pada peningkatan produksi pertanian. Melalui pemberdayaan masyarakat petani. Melalui pelatihan diharapkan kedepannya kualitas SDM pertanian dapat mampu meningkatkan kesejahteraan pelaku utama dan pelaku usaha dalam sub sektor tanaman pangan dan hortikultura ini.

\section{KESIMPULAN}

1. Komoditas padi merupakan komoditas pangan basis yang menyebar di sebagian besar kecamatan (22 kecamatan), komoditas hortikultura tanaman pisang menyebar di 15 kecamatan sementara tanaman belimbing, durian, kangkung dan kacang panjang menyebar di 14 kecamatan Kabupaten Tasikmalaya.

2. Komoditas yang menjadi prioritas pengembangan utama pada setiap 


\section{PENENTUAN KOMODITAS UNGGULAN SUB SEKTOR TANAMAN PANGAN DAN HORTIKULTURA DI SETIAP KECAMATAN KABUPATEN TASIKMALAYA \\ Yayu Setiani, Unang dan Betty Rofatin}

kecamatan

di

Kabupaten

Tasikmalaya yaitu komoditas padi menjadi prioritas pengembangan utama di 22 kecamatan; komoditas belimbing, durian, kangkung dan kacang panjang menjadi prioritas pengembangan utama di 14 kecamatan.

3. Komoditas yang menjadi unggulan pada setiap kecamatan di Kabupaten Tasikmalaya yaitu komoditas padi di 13 keca-matan, komoditas jagung, kedelai dan jambu biji di 8 kecamatan.serta komoditas nangka di 7 kecamatan.

\section{DAFTAR PUSTAKA}

Arief Daryanto dan Yundy Hafizrianda. 2010. Model-Model Kuantitatif Untuk Perencanaan Pembangunan Ekonomi Daerah. Bogor : IPB Press.

Badan Pusat Statistik. 2018. Kabupaten Tasikmalaya dalam Angka 2018. Badan Pusat Statistik Kabupaten Tasikmalaya. Kabupaten Tasikmalaya.

2019. Kabupaten Tasikmalaya dalam Angka 2019. Badan Pusat Statistik Kabupaten Tasikmalaya. Kabupaten Tasikmalaya.

2020. Kabupaten Tasikmalaya dalam Angka 2020. Badan Pusat Statistik Kabupaten Tasikmalaya. Kabupaten Tasikmalaya.

Balittanah.2021. Peluang

Pengembangan Komoditas
Sayuran di Kabupaten Indramayu dan Tasikmalaya. BALITBANGTAN_Kementrian Pertanian.

Balittanah.litbang.pertanian.go.i d?ind/index.php/berita/1653peluang-pengembangankomoditas-sayuran-dikabupaten-indramayu-dantasikmalaya

Budiman Achmad dan Ris Hadi Purwanto. 2014. Peluang Adopsi System Agrofo-restry dan Kontribusi Ekonomi Pada Berbagai Pola Tanam Hutan Rakyat di Kabupaten Ciamis. Jurnal Bumi Lestari, Volume 14 No. 1, Pebaruari 2014, hlm. 15 - 26

Cybex Pertanian. 2019. Budidaya Tanaman Manggis (Garciana Mangostana L. ). https//cybex.pertanian.go.id/mobil e/artikel/84587/BUDIDAYATANAMAN-M-A-N-G-G-I-SGarcinia-mangostana-L-/. Diakses pada tanggal 23 April 2021.

Cybex Pertanian. 2020. Budidaya Tanaman Buah Sawo. Error! Hyperlink reference not valid.. Diakses pada tanggal 29 April 2020.

Dinas Pertanian, Pangan dan Perikanan. 2020. Data Produksi Tanaman Buah-buahan Tahun 2020. Dinas Pertanian, Pangan dan Perikanan Kabupaten Tasikmalaya. Kabupaten Tasikmala-ya.

Dinas Pertanian, Pangan dan Perikanan. 2018. Data Produksi Tanaman Pangan Tahun 2018. Dinas Pertanian, Pangan dan Perikanan Kabupaten Tasikmalaya. Kabupaten Tasikmala-ya. 
Dinas Pertanian, Pangan dan Perikanan. 2019. Data Produksi Tanaman Pangan Tahun 2019. Dinas Pertanian, Pangan dan Perikanan Kabupaten Tasikmalaya. Kabupaten Tasikmalaya.

Ening Ariningsih. 2016. Peningkatan Produksi Ubi Kayu Berbasis Kawasan di provinsi Jawa Barat dan Sulawesi Selatan. Analisis Kebijakan Pertanian. 14(02).

Field, B.C. , MacGregor, B.D. 1993. Forcasting Techniques for Urban and Regional Planning, UCL Press, England .

Nani Zuraida (2009). Status Ubi Jalar Sebagai Bahan Diversifikasi Pangan Sumber Karbohidrat. Iptek Tanaman Pangan Vol. 4 No. 1 - 2009

Nur Rahmawati,Istiyanti Eni,dan Akbar Berlianllham (2019). Analisis Kela-yakan Finansial Usahatani Manggis di Kecamatan Puspahiang Kabupa-ten Tasikmalaya. Optimalisasi Sumberdaya Lokal Untuk Pembangunan Pertanian Terpadu dan Berkeadilan. ISBN : 978-6026697-47-9

Pemerintah Provinsi Jawa Barat. 2017. Profil Kabupaten Tasikmalaya. https://jabarprov.go.id/index.php/p ages/id/1046. Diakses pada tanggal 27Januari 2021.

Pusat Analisis Sosial Ekonomi dan Kebijak-an Pertanian. 2006. Warta Penelitian dan Pengembangan Pertanian. p. 1718. Vo. 28 N0.1,2006

Wahyudi s. m. s. 2017. Tipologi Daya Saing Kabupaten dan Kota di Jawa Timur. Senaspro 2. 2(1).

Widodo, T. 2007. Modul Praktikum Perencanaan Pembangunan. Yogyakarta: program Diploma Fakultas Ekonomi UGM.

World Bank. 2008. Agriculture For Development. World Bank. Washington, DC.

Zainal Abidin. 2018. Identifikasi Komoditas Unggulan Wilayah Dalam Perspektif Pertanian Berkelanjutan di Sulawesi Tenggara. Jurnal Mega Aktiva. $7(2)$. 